\title{
AMBIGUOUS SUBURBAN SPACES: TRENDS AND PECULIARITIES OF EVERYDAY PRACTICES CHANGE
}

\section{'Kostyantyn MEZENTSEV, Natalia PROVOTAR, Oleksiy GNATIUK, Anatolii MELNYCHUK, Olena DENYSENKO}

\author{
Taras Shevchenko National University of Kyiv, Ukraine
}

'k_mez@ukr.net

\begin{abstract}
The article presents the conceptualization of suburban space changes through the prism of changing everyday practices and its verification based on cases in the suburban areas of Kyiv and Vinnytsia. Given task is problematic both theoretically and empirically, as the suburban space is not only a physical residence place of the inhabitants, but also an environment of their life with all interactions and social relations. It is possible to speak about several main types of suburban spaces in Ukraine, each characterized by the specific nature of changes and the way of residents' life. Moreover, it is almost impossible nowadays to talk about the typical everyday life and everyday practices in the suburbia, as the latter becomes more and more heterogeneous as a result of the mixing, interaction and hybridization of various forms and practices, quite often within individual settlements. Investigating suburban inhabitants in the context of their daily life as residents, consumers, workers, and citizens through everyday practices provides an opportunity for a comprehensive understanding of the economic, social, cultural, and urban planning domains of the suburbia functioning in its relationship with the central city. Analyzed daily practices are related to the main components of human activity: accommodation, consumption, reproduction and upbringing of children, work, recreation, leisure and sports, education and cultural development, civic activity, mobility. The transformation of everyday practices is presented in the context of urban environment changes and emergence of new residents, orientation of residents to external interactions and meeting the needs in the central city/own settlement, mutual transformation and combination of old and new everyday practices. Changes in everyday practices have been identified in connection with the transformation of specific suburban areas, the behavior of residents and, ultimately, identity, and the factors of changes in everyday practices were revealed for different types of suburban spaces on the examples of Kyiv and Vinnytsia. The case studies show that transformations of the suburban spaces of Kyiv and Vinnytsia have similar driving forces, and the main consequences as well: radical change in population structure; loss or hybrid nature of the local identity of suburban settlements; advancing development of housing with underdeveloped engineering and social infrastructure; increasing heterogeneity, fragmentation and polycentricism of suburban spaces; growing the suburbia's dependence on the central city.
\end{abstract}

Key words: suburbia, suburban spaces, suburbanism, everyday practices, Kyiv, Vinnytsia.

DOI: https://doi.org/10.17721/2413-7154/2019.82.4-19

UDC: 911.3

Received: November 22, 2019.

Revised: December 12, 2019.

Accepted: December 16, 2019.

\section{НЕОДНОЗНАЧНІ ПРИМІСЬКІ ПРОСТОРИ: ТЕНДЕНЦІЇ ТА ОСОБЛИВОСТІ ЗМІНИ ПОВСЯКДЕННИХ ПРАКТИК}

\author{
'КостЯнТИН МЕЗЕНЦЕВ, НатаЛія ПРОВОТАР, ОЛЕКСіЙ ГНАТЮК, АНатоліЙ МЕЛЬНИЧУК, ОЛЕНа ДЕНИСЕНКО
}

\author{
Київський національний університет імені Тараса Шевченка, Україна \\ ${ }^{1} k \_$mez@ukr.net
}

\begin{abstract}
Анотація: У статті представлено концептуалізацію змін приміських просторів через призму мінливих повсякденних практик та її перевірка на матеріалах кейсів у приміських просторах Києва та Вінниці. Це завдання $\epsilon$ проблематичним як теоретично, так і емпірично, оскільки приміський простір $\epsilon$ не лише місцем фізичного перебування мешканців, але й середовищем їх життєдіяльності з усіма взаємодіями і соціальними відносинами. Можна вести мову про декілька основних типів приміських просторів України, для кожного з яких характерні специфічні характер змін та спосіб життя мешканців. До того ж, нині практично неможливо говорити про типове повсякденне життя та повсякденні практики в субурбії, оскільки вона стає все більше неоднорідною внаслідок змішування, взаємодії та гібридизації різноманітних форм і практик, досить часто в межах окремих населених пунктів. Дослідження мешканців передмість в контексті їх життєдіяльності як жителів, споживачів, працівників, громадян через повсякденні практики дає можливість комплексного пізнання економічних, соціальних, культурних, містобудівних сфер функціонування передмість у їх взаємозв'язку з містом-центром. Проаналізовані повсякденні практики пов'язані 3 основними складовими людської діяльності: проживання, споживання, відтворення та виховання дітей, робота, відпочинок, дозвілля та спорт, освіта та культурний розвиток, громадська діяльність, мобільність. Перетворення повсякденних практик представлено у контексті змін міського середовища та появі нових мешканців, орієнтації мешканців на зовнішні взаємодії та задоволення потреб у центральному місті/власному населеному пункті, взаємне перетворення та поєднання старих і нових повсякденних практик. Виявлені зміни повсякденних практик, пов'язані із перетворенням конкретних ділянок приміського простору, поведінки мешканців та, зрештою, ідентичності. Визначені фактори змін повсякденних практик у різних типах приміських просторів на прикладі Києва та Вінниці. Аналіз кейсів показує, що рушійні сили трансформації приміських просторів Києва та Вінниці в загальних рисах є подібними. Подібними $є$ також наслідки трансформацій: радикальна зміна структури населення; втрата або гібридний характер місцевої ідентичності приміських поселень; випереджаючий розвиток житлової забудови за відставання розвитку відповідної інженерної та соціальної інфраструктури; наростаюча неоднорідність, фрагментарність та поліцентричність приміських просторів; посилення залежності субурбії від центрального міста.
\end{abstract}

Ключові слова: субурбія, приміські простори, субурбанізм, повсякденні практики, Київ, Вінниця. 


\section{Постановка проблеми: неоднозначні приміські простори}

У 1970-80-х роках відбулося переосмислення категорії простору в суспільній географії: його стали розглядати не як такий, де соціальні характеристики диференціюються (i відповідно картографуються), а як такий, де соціальні відносини «розгортаються», а сам простір формується в процесі соціальних відносин - відбувається виробництво простору (Мезенцев і Мезенцева 2018). Соціальні та просторові відносини надалі розглядаються як «співдетермінанти» (Smith et al. 2010), а проблеми, негаразди, нерівність - не просто як «соціальні», що проявляються в «просторі», а як «соціальнопросторові». Йдеться й про соціально-просторову діалектику, коли, з одного боку, люди створюють, модернізують простір, але 3 іншого - залежать від простору, в якому живуть і працюють (Knox and Pinch 2010).

У більшості досліджень метрополітенських регіонів головний фокус зосереджується на центральних містах, а субурбія, що трактується як периферія в просторі регіону, стає «периферією» i в теоретичному дискурсі. Хоча формування периферійних територій $€$ невід'ємною складовою процесу розвитку будь-якої території, іншою стороною процесу формування центрів, більше уваги отримують саме процеси формування центрів, ядер людської діяльності (Mezentsev 2012). Натомість той факт, що більшість мешканців США проживає у субурбії, дозволило за аналогією 3 «урбаністичним століттям» вести мову про початок «субурбаністичного століття» (Schneider 1992). В Україні субурбія ще не набула таких масштабів, але іï значення у розвитку метрополітенських регіонів суттєво зростає.

Як зазначає Е. Соджа, концептуалізація приміських просторів $є$ проблематичною як теоретично, так і емпірично (Soja 2011), тобто дослідження приміських просторів складне завдання, а самі приміські простори є неоднозначними. Приміські простори - це не лише місця фізичного перебування мешканців, але й середовище їх життєдіяльності 3 усіма взаємодіями і соціальними відносинами. Дослідження мешканців передмість в контексті їх життєдіяльності як жителів, споживачів, працівників, громадян через повсякденні практики дає можливість комплексного пізнання економічних, соціальних, культурних, містобудівних сфер функціонування передмість у їх взаємозв'язку 3 містом-центром.

В міру розвитку суспільства посилюються процеси диференціації субурбії і навіть формування нових іï типів. Європейська субурбія $\epsilon$ водночас «старою» і «новою», тому Н. Фелпс веде мову про те, що Європа є цікавою з точки зору спостереження за сучасними процесами субурбанізації (Phelps 2017). А М. Уреднічек зазначає, що субурбанізація постсоціалістичних міст належить до найбільш привабливих наукових напрямів сучасної суспільної географії (Ouředníček 2007). Такі дослідження мають важливе значення не лише через унікальність траєкторії субурбанізації в умовах пост-соціалізму, але також відкривають специфічну та цікаву перспективу теоретизації процесів субурбанізації (Stanilov and Sykora 2014).

Вивчення субурбії в різних країнах світу показує, що їхня різноманітність - це швидше норма, а не виняток. Хоча домінуючі типи субурбії відрізняються за регіонами і містами та залежать від локального контексту, останні тенденції свідчать про переважання змішаних рис, коли різні типи субурбії співіснують на одній території (Shen and $\mathrm{Wu}$ 2013). Для того, щоб повніше зрозуміти приміський спосіб життя, розвинути його концептуалізацію, необхідно дослідити, як місцеві мешканці самі розуміють, сприймають та трактують субурбію, що про неї думають i говорять (Harris 2010). Це можливо зробити шляхом вивчення такого прояву приміського способу життя як повсякденні практики місцевих мешканців.

Нині практично неможливо говорити про типове повсякденне життя та повсякденні практики в субурбії, як раніше, коли уявлення про них формувалося на основі вивчення приміських просторів американських міст у післявоєнний час. Субурбія все більше стає неоднорідною, стає місцем, де змішуються різноманітні форми та практики, де поряд розміщуються низькоповерхова приватна забудова та багатоповерхові житлові комплекси, співіснують заможні, середній клас та бідніші прошарки населення, де розмиваються уявлення про «фемінізовану» субурбію та «маскулінізоване» місто (Drummond and Labbé 2013) тощо. Недарма К. Андерсон задає питання, чи субурбанізмдвадцятьпершогостоліття $€$ міським способом життя зі своїм набором визначених культурних та ландшафтних цінностей? (Anderson 2006).

Метою даної статті $є$ концептуалізація змін приміських просторів через призму мінливих повсякденних практик та ̈ї перевірка на матеріалах кейсів у приміських просторах Києва та Вінниці.

\section{Зміни приміських просторів через призму повсякденних практик: мінливий повсякденний субурбанізм}

Нині існуе велике різноманіття процесів та результатів субурбанізації, як за формою, так i структурою (Keil 2018). Традиційними ознаками субурбії та приміського способу життя є низька щільність населення, переважання приватних односімейних будинків та істотна залежність від автомобілів. Також серед типових рис називають 
прагнення жити в природному оточенні, однорідність соціального середовища, тісніші контакти в межах місцевої громади. Ці ознаки принципово відрізняли субурбію від міста, приміський спосіб життя від міського. I в цілому субурбія, на відміну від різноманітного міста, розглядалася як гомогенне утворення.

Практично всі ці типові ознаки зазнають змін, інколи «міняючись місцями». Так, субурбія стає все більш різноманітною, поєднуючи різні типи забудови (квартали висотних будинків, низькоповерхові будинки та різноманітні їх поєднання), різні категорії населення, різні види економічної діяльності, i, як наслідок, різні повсякденні практики (Shen and Wu 2013; Keil 2018 та ін.). Водночас тіснота контактів та взаємодії у приміських громадах зменшується.

Внутрішні відмінності тепер можуть розглядатися як визначальна характеристика субурбії, а міста стають більш однорідними, тоді як субурбія зростає різноманітнішою (Crawford 2015). Ще у 1970-х роках Л. Масотті писав, що «найсуттєвішою зміною у визначенні сучасної субурбії може стати і1і зростаюча економічна незалежність від центрального міста... Вона стає все менш приміською і більш міською» (Massotti 1973).

М. Мікельбанк на основі аналізу недавніх досліджень субурбії зробив висновки, що 1) приміські простори не $є$ однорідними, процвітаючими спальними громадами, якими вони створювалися, 2) їх населення не $є$ расово, економічно чи соціально однорідним, 3) приміська влада не завжди має достатньо ресурсів, низькі податки, якісні школи та бездоганну інфраструктуру (Mikelbank 2004). Саме субурбія тепер є неодноманітною, а складається 3 різних часткових просторів, які «дозріли для змін, щоб відобразити потреби адаптації до змін клімату, управління економічними кризами та соціальних зрушень у демографічній та сімейній структурі» (Jessen and Roost 2015).

3 точки зору дослідження різних типів субурбії (на прикладі (пост)-субурбії Франції та Канади) було запропоновано цікаву метрику, де для різних типів субурбії (від внутрішньої субурбії до віддалених пері-урбаністичних окраїн) виділено характерні типи населення (за класом, доходами), переважаючі типи (міської) політики, головні актори та (що особливо важливе 3 точки зору даного дослідження) головні морфологічні зміни (Charmes and Keil 2015).

Якщо серед головних фізичних характеристик субурбії традиційно відмічали низьку щільність та периферійність, а також наявність лише одного типу землекористування, що зумовлює необхідність щоденних поїздок місцевих мешканців,то Р. Гарріс додає іншу важливу характеристику, яка часто недооцінюється - «новітність субурбіï» (Harris 2010). Саме новітність, як щодо часу виникнення, так і щодо зміни стає одним із ключових факторів мінливості повсякденних практик у приміських просторах. Як швидко приміські простори у свідомості ï мешканців перестають бути субурбією (а сприймаються власне як місто) залежить від того, як швидко триває їі розвиток, які зміни у «приміській тканині» відбулися. Тобто потрібно зрозуміти, що відбувається в субурбії після того, як вона розвинулась, як вона «старіє» (Harris 2010; McManus\&Ethington 2007).

Субурбія європейських країн характеризується значною «різноманітністю, очевидною за ïx формою та способами управління, а також змішуванням цих форм i способів в окремих національних умовах» (Phelps etal. 2015). Так, якщо на периферії постсоціалістичних міст раніше переважали стандартизовані житлові комплекси для працівників державних підприємств, то після розпаду соціалістичної системи стала очевидною

Таблиияя 1. Типи приміських просторів (Мезенцев 2017)

\begin{tabular}{|c|c|c|c|c|c|}
\hline & $\begin{array}{l}\text { Сільські посе- } \\
\text { лення, охоплені } \\
\text { субурбанізацією }\end{array}$ & $\begin{array}{c}\text { Нові } \\
\text { котеджні } \\
\text { містечка }\end{array}$ & $\begin{array}{c}\text { Перетворені на } \\
\text { постійні дачні } \\
\text { поселення }\end{array}$ & $\begin{array}{c}\text { Зростаючі міста- } \\
\text { супутники радян- } \\
\text { ських часів } \\
\end{array}$ & $\begin{array}{c}\text { Райони } \\
\text { внутрішньої } \\
\text { субурбанізації }\end{array}$ \\
\hline Характер змін & $\begin{array}{c}\text { нова забудова / } \\
\text { оновлення- } \\
\text { модернізація / } \\
\text { знесення та } \\
\text { будівництво нового } \\
\text { житла } \\
\end{array}$ & $\begin{array}{c}\text { нова } \\
\text { забудова }\end{array}$ & $\begin{array}{c}\text { оновлення- } \\
\text { модернізація / } \\
\text { знесення та } \\
\text { будівництво } \\
\text { нового житла }\end{array}$ & $\begin{array}{c}\text { нова забудова / } \\
\text { “втиснення” } \\
\text { окремих будинків } \\
\text { у старі } \\
\text { мікрорайони }\end{array}$ & \begin{tabular}{|c} 
нова забудова / \\
оновлення- \\
модернізація / \\
знесення та \\
будівництво нового \\
житла \\
\end{tabular} \\
\hline $\begin{array}{l}\text { Переважаючий } \\
\text { тип житла }\end{array}$ & $\begin{array}{c}\text { низько-поверхова } \\
\text { індивідуальна } \\
\text { забудова / } \\
\text { багато-поверхова } \\
\text { забудова }\end{array}$ & $\begin{array}{c}\text { низько- } \\
\text { поверхова } \\
\text { індивідуальна } \\
\text { забудова, } \\
\text { таунхауси }\end{array}$ & $\begin{array}{c}\text { низько- } \\
\text { поверхова } \\
\text { індивідуальна } \\
\text { забудова }\end{array}$ & $\begin{array}{c}\text { багато-поверхова } \\
\text { забудова }\end{array}$ & $\begin{array}{c}\text { низько-поверхова } \\
\text { індивідуальна } \\
\text { забудова }\end{array}$ \\
\hline Спосіб життя & $\begin{array}{c}\text { приміський / } \\
\text { сільський }\end{array}$ & $\begin{array}{l}\text { приміський / } \\
\text { “другий дім” }\end{array}$ & $\begin{array}{l}\text { приміський / } \\
\text { “другий дім” }\end{array}$ & $\begin{array}{c}\text { приміський / } \\
\text { міський }\end{array}$ & міський \\
\hline $\begin{array}{l}\text { Оточуючий } \\
\text { простір }\end{array}$ & сільський & $\begin{array}{l}\text { сільський / } \\
\text { відкритий }\end{array}$ & $\begin{array}{c}\text { сільський / } \\
\text { відкритий }\end{array}$ & міський & міський \\
\hline
\end{tabular}


житлова децентралізація, коли в субурбії з'явилися райони проживання більш заможного населення та середнього класу (Hirt, 2012).

Україна також субурбанізується нерівномірно. Процеси трансформації приміських просторів суттєво відрізняються навколо великих міст країни, а різні їх частини змінюються порізному (Мезенцев 2017). Можна вести мову про п'ять основних типів приміських просторів, для кожного з яких характерні специфічні характер змін, переважаючий тип житла, спосіб життя та оточуючі простори - сільські поселення, охоплені субурбанізацією, нові котеджні містечка, перетворені на постійні дачні поселення, зростаючі міста-супутники радянських часів, а також райони внутрішньої субурбанізації (табл. 1).

Субурбанізація розглядається як процес, субурбія як місце, а субурбанізм - як специфічний приміський спосіб життя (Keil 2018). Зважаючи на різноманітність субурбії, може здаватися неможливим ідентифікувати спільні риси субурбанізму, приміського способу життя (Harris 2015).

Вперше термін субурбанізм був запропонований соціологом С. Фавою у $1950-\mathrm{x}$ роках як «третій шлях» між концепціями урбанізму та руралізму, як специфічний соціо-психологічний стан і паттерн - приміський спосіб життя (Fava 1956). Розбіжності між міським і сільським способом життя зазвичай розглядали через відмінності у чисельності населення, щільності забудови та ступені однорідності. Ключовою специфікою субурбанізму С. Фава визначила «сусідство» і «добросусідство» (neighbouring and neighbourliness), а також інші сільські цінності та практики, що відрізняють субурбанізм від урбанізму (Fava 1956).

Якщо дослівно «субурбаністичний» означає «менший, ніж урбаністичний», то, на думку, А. Волкса, субурбанізм, може розумітися як «обмежений або підпорядкований урбанізм», а якщо його визначити як «недоурбанізм», то субурбанізм є відсутністю «повного урбанізму», але не свідчить про його повну відсутність (Walks 2013). Проте далі А. Волкс задає питання, чи слід вважати субурбанізм як соціальнопсихологічну формацію третім способом, відмінним від урбанізму та руралізму, чи, можливо, це гібридна формація, що включає вибрані елементи обох? (Walks 2013). I, нарешті, робить висновок про існування «множинності субурбанізмів» (Walks 2013).

Л. Драммонд та Д. Лаббе ведуть мову про «повсякденний субурбанізм», підкреслюючи доцільність застосування якісних методів дослідження (зокрема глибинних інтерв'ю) для його розуміння, на відміну від традиційної кількісної оцінки відмінностей між міським і приміським способом життя (Drummond and Labbé 2013). При цьому «дослідження приміського повсякденного життя ... вимагають уваги до практик та просторів соціальної взаємодії в усьому спектрі приміських місць та форм», що зустрічаються все частіше по всьому світу, і особливо за межами субурбії міст глобальної Півночі (Drummond and Labbé 2013).

Приміська культура отримує все більше уваги по мірі збільшення розмаїття в субурбії, зростає увага до «культурного життя передмістя», нових культурних практик (Keil 2018). Також важливо акцентувати увагу на тому, що поняття «субурбія» позначає не тільки тип місця, але й тип людини (Harris 2015).

Повсякденне життя можна розглядати 3 точки зору різних аспектів: 1) як сукупність сформованих повсякденних практик, 2) як основу, на якій формуються повсякденні практики та 3) як потік взаємодій місцевих мешканців. Під поняттям повсякденної практики, як правило, розуміють спосіб дії людей в тій чи іншій ситуації. Повсякденні практики у приміських просторах це звичайні, ординарні щоденні практики, рутинні активності ординарних людей, проживання повсякденного життя, непомітні форми життя, що приймаються як належне, щоденні практики, про які зазвичай не думають (Horton and Kraftl 2014; MacKay 1997; Chaney 2002).

Життєдіяльність людини включає економічну, соціальну, політичну та духовну сфери. У кожній 3 них реалізуються певні соціальні практики, які включають різні форми і види. Низовим рівнем соціальних практик $\epsilon$ ті, які пов'язані із щоденним життям - повсякденні практики. Найпоширеніші ї форми пов'язані із основними складовими людської діяльності, такі як:

- проживання - повсякденні практики використання житла, його облаштування, використання прибудинкових територій;

- споживання - повсякденні практики здійснення покупок, отримання послуг та харчування;

- відтворення - повсякденні практики виховання дітей;

- робота - повсякденні практики здійснення трудової діяльності;

- відпочинок, дозвілля, спорт - повсякденні практики відновлення фізичних сил та духовних i інтелектуальних здібностей, проведення вільного часу та підтримки активного способу життя;

- освіта та культурний розвиток - повсякденні практики пізнання;

- громадська діяльність - повсякденні практики самоорганізації громади;

- мобільність - повсякденні практики переміщення.

Можна вести мову про повсякденні практики як окремих осіб, так і певних спільнот, виділених за різними ознаками: територіальною (повсякденні практики жителів різних субрегіонів, країн і регіонів світу тощо); національною (повсякденні практики українців, японців, французів тощо); способом життя (повсякденні практики селян, містян, жителів передмість тощо); віком 
(повсякденні практики підлітків, людей старших вікових груп тощо); статтю (повсякденні практики чоловіків і жінок); сімейним станом (повсякденні практики сімей 3 дітьми, без дітей, одиноких жінок/чоловіків 3 дітьми, молодих матерів тощо); професійною (повсякденні практики офісних працівників, вчителів, лікарів тощо); статусом (повсякденні практики менеджерів, службовців, робітників тощо); майновою (повсякденні практики бідних, представників різних прошарків середнього класу, заможних); релігійною (повсякденні практики християн, мусульман тощо).

Перелік ознак для виділення спільнот 3 особливими повсякденними практиками не може бути вичерпним в силу мінливості останніх. Водночас, варто зауважити, що повсякденні практики складніше ідентифікувати, якщо структура населення певної території неоднорідна за статусом, доходами, віком, сімейним станом. При цьому, чим абстрактнішою $є$ виділена спільнота, тим складніше визначити її об'єднуючі повсякденні практики.

Особливості повсякденних практик жителів приміських просторів визначаються високим рівнем їх щоденної мобільності, що позначається, насамперед, на практиках трудової діяльності, отримання різних послуг та споживання, відпочинку та дозвілля.

Просторовими індикаторами повсякденних практик населення є локалізація (віддаленість, відстань, поєднання) та мобільність (способи, періодичність, дальність, часові витрати). Вони визначають конфігурацію простору повсякденного життя. У приміських просторах повсякденні практики можуть мати різні конфігурації: бути повністю зосереджені у межах місця проживання в субурбії; зосереджені переважно в межах місця проживання в субурбії, але й частково у місті; зосереджені в місті і лише незначною мірою у місці проживання в субурбії; однаковою мірою зосереджені як у місці проживання в субурбії, так і у місті.

Субарбанізм не є статичною характеристикою певних просторів, це багатовимірний еволюціонуючий процес в рамках урбанізму, який «постійно коливається і пульсує». Різні простори, таким чином, «наповнені» різним рівнем і гібридністю форм субурбанізму (Walks 2013). Зміни приміських просторів слід розглядати двояко: якщо на одному рівні - це процес «масового» будівництва та перебудови міських окраїн (включаючи процеси постсурбанізації), то на другому рівні - поява нових повсякденних субурбанізмів, нових приміських способів життя (Keil 2018).

Цікавою $\epsilon$ ідея А. Волкса, який визначив шість вимірів, що розрізняють ідеальні типи урбанізму та субурбанізму, щодо яких будь-яке місце (приміський простір) може демонструвати незмінність (або повільну зміну) уздовж одного виміру, при цьому досить швидку зміну уздовж іншого. Відповідно, залежно від зміни за різними вимірами, може бути ідентифікований, наприклад, автомобільний, сецесіоністський чи ексклюзивний субурбанізм, або диверсифікований,інноваційний, багатофункціональний та полімобільний субурбанізм, може бути визначений субурбанізм домашності, сусідства та ізольованості, або субурбанізм громадськості та колективної мобілізації (Walks 2013).

Е. Коткін висунув ідею «нового субурбанізму» як практичного та корисного способу вирішення основних проблем, що стоять перед субурбією, спрямований передусім на підтримку розвитку «напівавтономних сіл» по всій периферії міст (Kotkin 2005). Подібно до нового урбанізму він наголошує на важливості публічних та відкритих просторів, а також розвиту громади, заперечуючи, що приміське життя $\epsilon$ «неестетичним та марнотратним», а навпаки, вважає субурбію «гарним місцем для життя більшості людей», що потребує пошуку шляхів як зробити його кращим (Kotkin 2005).

Повсякденне життя визначається та характеризується появою, зміною та зникненням соціальних практик (Shove and Pantzar 2012), a 3 ïх допомогою можуть бути описані та визначені фактично будь-які соціальні феномени. Відтак, соціальні практики є вдалим способом ідентифікації, пізнання та відображення значимих суспільних змін з метою формування відповідної політики розвитку приміських просторів.

Сучасними рисами повсякденних практик $€$ мінливість та індивідуалізація. Урбанізаційні процеси суттєво впливають на спосіб життя людей в сенсі посилення різноманітності та надання кожному значної свободи у виборі моделей і форм повсякденної поведінки у різних сферах життєдіяльності. Наприклад, повсякденне життя людей наповнюється новими цифровими технологіями, які стають повсякденними атрибутами способу життя. Іншим прикладом $є$ майнове розшарування суспільства, при якому для одних людей життєвий простір розширюється, а для інших - звужується за рахунок зниження рівня доступності окремих повсякденних практик (Провотар та ін. 2019).

Кожна практика має кілька визначальних елементів: матеріально-речові компоненти (матеріальна складова), компетенції (способи iii реалізації), а також соціальна та символічна значимість (емоційна складова) (Shove and Pantzar 2012). Відповідно, зміна будь-якої складової, наприклад, технічний прогрес, поява нових способів їі здійснення (форм організації) чи суспільної значимості (трендів), або модифікує саму практику та способи іiі здійснення, або призводить до іï переформатування, а подекуди - витіснення та заміщення іншими, оновленими/ новими практиками.

«Коли заходить мова про те, як і де ми мешкаємо, працюємо і розважаємося, ми живемо у час швидких змін», «урбанізація позначає момент 
нашого спільного досвіду як планетарних жителів» (Keil 2018). У контексті повсякденних практик, це означає їх певну уніфікацію, стандартизацію та наближення способів їх реалізації у зв’язку з загальним планетарним процесом урбанізації. Навіть сама субурбанізація давно перетворилася на глобальний процес (Keil 2018). У цьому зв'язку міські та приміські практики більшості регіонів проходять достатньо схожий шлях 3 формування певного набору відносно стандартних, типових, практик, коли межа між міськими та приміськими просторами стирається настільки сильно, що ¥ї складно виявити.

Дихотомія міських та сільських просторів супроводжується процесом розмивання типових характеристик, що їх визначають (Dymitrow and Stenseke 2016), стиранням межі між ними. Водночас, навіть зараз, після тривалого часу інтенсивного тиску великих міст на «старі» приміські простори, все ще можуть бути ідентифіковані окремі «старі» приміські практики, що зберігають своє значення поряд 3 новими. Таким чином, в окремих приміських просторах завдяки поєднанню низки чинників зберігаються специфічні приміські практики, що відображають риси попередніх часових зрізів, а також виникають нові гібридні форми.

Причинами змін повсякденних практик можуть бути: вимушена відмова від старих повсякденних практик або їх трансформація під тиском об'єктивних причин (наприклад, зміна місця проживання, місця роботи, зниження чи збільшення доходів, хвороба тощо); зміна середовища проживання як в географічному, так і соціальному сенсі, що пов'язана із необхідністю враховувати нові повсякденні практики, сформовані в інших політичних, соціальноекономічних чи культурних умовах проживання.

Мінливість повсякденних практик найдинамічніше проявляється у приміських просторах, де взаємонакладаються кілька зрізів повсякденних практик тих, хто поселяється в субурбії: повсякденні практики жителів міст i сільської місцевості; повсякденні практики жителів різних регіонів, які можуть мати суттєві соціально-психологічні відміни; повсякденні практики тих, хто розглядає передмістя як територію тимчасового проживання на шляху до поселення в місті, і тих, хто поселяється на тривалий період часу.

Хронологічно першим процесом $є$ субурбанізація міських та сільських поселень приміської зони, проявом якої є поява приміських практик, що існують у одному i тому самому поселенні паралельно із традиційними міськими чи сільськими практиками та поступово витісняють останні. Ключовим елементом приміського способу життя є специфічний характер мобільності населення - щоденні маятникові міграції 3 передмістя до міста та у зворотному напрямку. Активність типових «приміських жителів» практично повністю пов'язана із центральним містом, тоді як передмістя виконує для них лише функцію спального району. Не останню роль у формуванні такого типу субурбії відіграє наявність та якість транспортної інфраструктури. Ландшафт передмістя формується здебільшого одноманітний та монотонний, 3 гіпертрофією житлової забудови, в той час як власна сфера послуг, у тому числі соціальна інфраструктура, залишається недорозвиненою. Традиційна ідентичність поселення при цьому розмивається або взагалі втрачається на користь ідентичності 3 центральним містом.

Подальший розвиток власної соціальної та виробничої інфраструктури такої субурбії може призводити до наступної стадії - заміщення приміських практик типово міськими, оскільки щонайменше частина мешканців отримує можливість працювати та задовольняти більшість своїх потреб в межах самого передмістя. Життя таких мешканців зосереджується у приміській зоні, оскільки потреба для регулярних візитів у місто зникає. На цій стадії можливе відновлення місцевої ідентичності, проте вже як ідентичності міської, 3 новим набором цінностей та перцепційних домінант. Результатом $є$ так звана урбанізація субурбії, коли приміські поселення зливаються 3 центральним містом, перетворюючись на його райони, або функціонують у вигляді міст-супутників. Проте, можливий i процес руралізації субурбії внаслідок конкуренції приміських та сільських практик, зокрема набуття останніх населенням субурбії (наприклад, ведення приміськими жителями особистого підсобного господарства).

Зміни повсякденних практик можуть супроводжуватись певними конфліктами, протестами. Їх ймовірність зростає залежно від згуртованості громади, традицій, вкоріненості повсякденної практики, тривалості їі існування. На думку, А. Ортеги, в умовах «неоліберального виробництва приміських просторів» проявляються як креативні, так і деструктивні процеси. При цьому на сусідніх приміських просторах можуть відбуватися діаметрально протилежні процеси. Так, на прикладі Філіппін він показав, як «повсякденна географія» нових мешканців закритих поселень (gated communities) контрастує з ї сусідами з фермерських громад (Ortega 2012).

\section{Приміські простори Києва: мінливі чи стійкі повсякденні практики?}

Приміські райони Києва характеризуються додатнім сальдо міграції за рахунок тих, хто приїхав на навчання/роботу до столиці і має бажання не орендувати житло у Києві, а придбати власне за низькою/нижчою ціною. Тривалий в часі (з початку 1990-х років), постійний і чисельний суспільний запит на переселення до приміської зони Києва, викликаний престижністю проживання «майже в столиці» та соціальноекономічними перевагами, які 3 цим пов'язані, 
стимулює будівельний бум у приміських простоpax на мінімально можливій відстані від столиці. 32014 року до потужного потоку бажаючих жити в передмісті Києва додалися вимушено переселені особи 3 тимчасово окупованих територій Донецької та Луганської областей. Як результат, в сільських поселеннях 32008 року дуже швидко будуються житлові комплекси та котеджні містечка.

Кейс Софіївська Борщагівка - це лише один 3 прикладів будівництва житлових мікрорайонів у столичному передмісті. Чинниками стрімкого

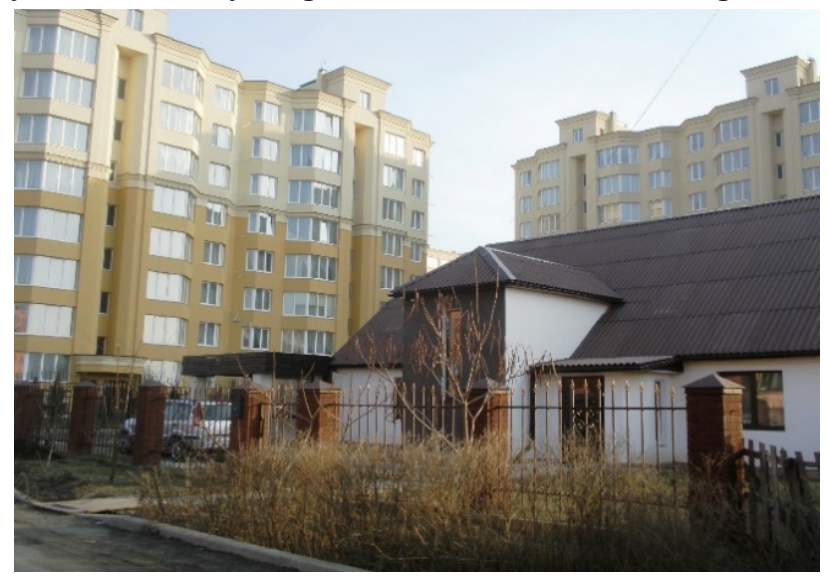

заселення Софіївської Борщагівки є низькі ціни на житло (на 20-30\% нижчі, ніж у Києві), наявність індивідуальних опалювальних систем, спрощена процедура кредитування та близькість до столиці (Софіївську Борщагівку від Києва відділяє лише Кільцева дорога, а нова забудова розпочиналась на землях закинутого тепличного господарства агрокомбінату «Пуща Водиця» на відстані 1 км від неї).

Частина нової забудови Софіївської Борщагівки здійснюється на сільськогосподарських землях без зміни їх цільового призначення.

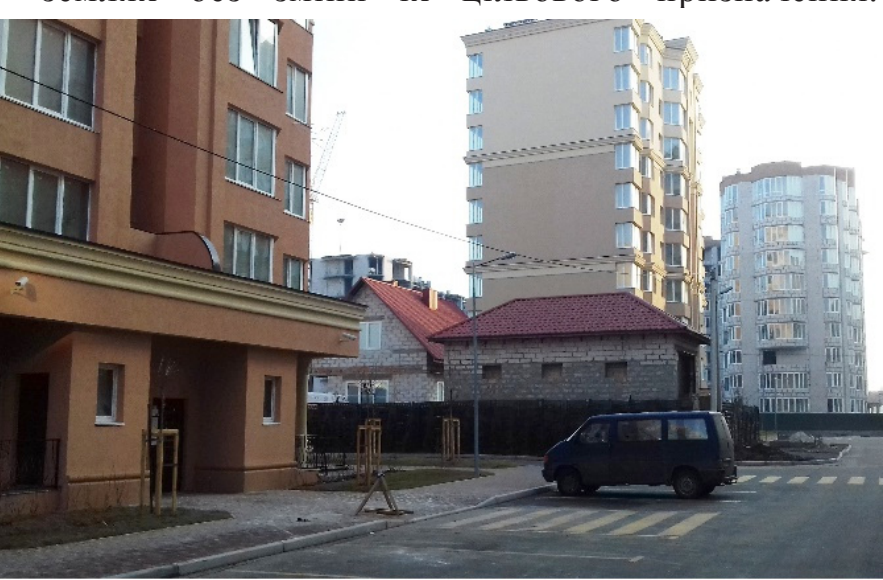

Рис. 1. Нова забудова у Софіївській Борщагівці (Фото: Н. Провотар, 2017 рік)
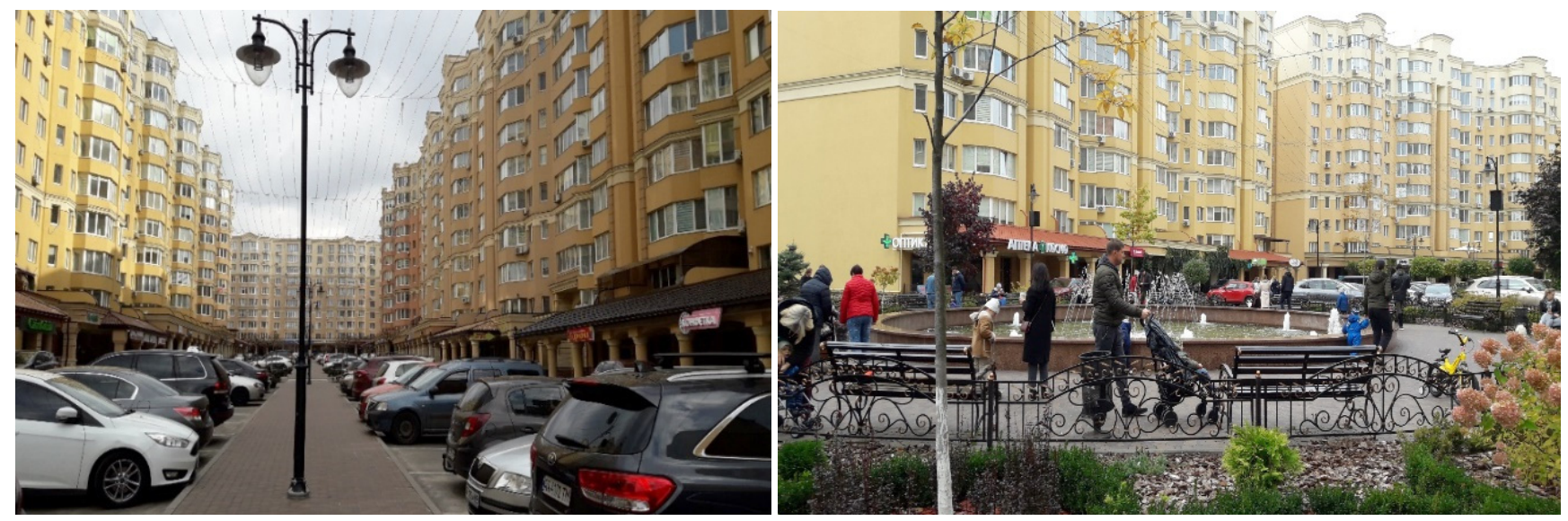

Рис.2. Публічні простори новобудов Софіївської Борщагівки (Фото: Н. Провотар, 2019 рік)
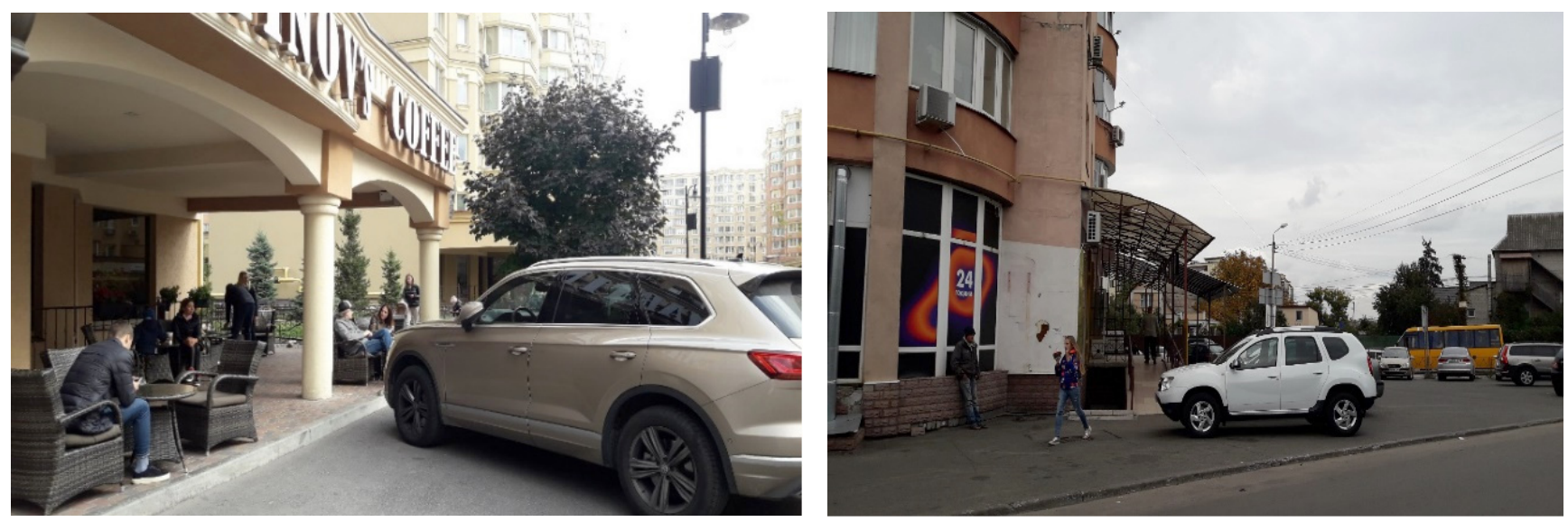

Рис. 3. Повсякденні практики проведення дозвілля жителями новобудов та старої (історичної) частини Софіївської Борщагівки (Фото: Н. Провотар, 2019 рік) 
У зв'язку з цим місцева громада протестує проти незаконної роздачі сільською радою земель під будівництво багатоповерхових житлових комплексів та продажу землі несільськогосподарського призначення нижче ринкової і нижче нормативної оцінки землі. Площа села Софіївська Борщагівка (1810 га) затверджена проектом землеустрою в зв'язку зі зміною меж села відповідно до Генерального плану забудови села (2013 р.) збільшилася на 713 га.

У Софіївській Борщагівці передбачається будівництво понад двох десятків нових житлових комплексів. Вони фактично утворюють самостійні спальні райони 3 доволі високою щільністю багатоповерхової забудови. Більшість житлових комплексів побудовано на відкритих просторах. Нова забудова села включає два ареали: ареал житлових комплексів вздовж Кільцевої дороги 3 5-11-поверховою забудовою та ареал житлових комплексів вздовж траси від Кільцевої дороги до c. Петрівське із 5-12-типоверховою забудовою. Між дорогами також розміщені окремі житлові комплекси. Окремим ареалом сучасного села $€$ стара (історична) його частина 3 приватною забудовою та невеликою кількістю будинків висотою до чотирьох поверхів. Генеральним планом села передбачена кількість жителів 115 тис. осіб. Тобто при реалізації всіх будівельних проектів нові жителі села будуть суттєво перевищувати чисельність корінних жителів (6571 особа у 2001 р. ), що проявиться у суттєвій зміні стилю та способу життя мешканців Софіївської Борщагівки.

Трансформації у Софіївській Борщагівці відбуваються швидкими темпами, здійснюються при визначальному впливі ринку нерухомості i мають різний прояв в старій (історичній) частині села та в районах житлових новобудов (Провотар та ін. 2019).

У селі відсутній єдиний громадський центр, який би об'єднував мешканців. Кожен із трьох ареалів Софіївської Борщагівки має свій власний громадський центр та публічні простори, щоденні практики споживання, відпочинку та проведення дозвілля в яких суттєво відрізняються. На перспективу на досить віддаленій від кожного 3 трьох ареалів території планується будівництво торговельно-розважального центру, який, можливо, буде виконувати функції основного публічного простору села i стане основою формування єдиного громадського центру. Тобто нині в Софіївській Борщагівці можна спостерігати різноманіття субурбії та множинність субурбанізмів у межах навіть одного населеного пункту, а не лише в межах Київського метрополітенського регіону чи метрополітенських регіонів України.

У Софіївській Борщагівці взаємонакладаються кілька зрізів повсякденних практик мешканців двох ареалів нової забудови: повсякденні практики новоприбульців із сіл та із міст; повсякденні практики новоприбульців із різних регіонів України (найбільше у новозбудованих житлових комплексах спостерігається припаркованих автомобілів із номерами Донецької, Дніпропетровської, Луганської, Полтавської, Київської, Вінницької областей). Попри це в ареалі старої забудови села повсякденні практики також відрізняються. Для прикладу розглянемо окремі специфічні аспекти повсякденних практик проживання, проведення дозвілля та мобільності мешканців Софіївської Борщагівки.

У Софіївській Борщагівці має місце унікальне для забудови явище: поряд із багатоповерховою забудовою в межах житлових комплексів та між ними знаходяться поодинокі приватні будинки 3 обгородженою парканом територією (рис. 1). Більшість 3 них були сплановані чи побудовані ще до початку нової інтенсивної забудови території житловими комплексами, тому їх власники вимушені були обрати варіант «несумісного сусідства». I на це необхідно зважати, оскільки конфігурація будинків та міст має прямий вплив на повсякденне життя (Hillier and Hanson 1984). Щоденні практики проживання мешканців багатоквартирної висотної та приватної забудови суттєво відрізняються в сенсі облаштування та використання житла і двору.

У Софіївській Борщагівці спостерігається недостатня кількість, а подекуди і відсутність публічних просторів, зокрема парків, скверів, торговельно-розважальних комплексів тощо. Головним публічним простором ареалу новобудов $€$ «місцевий Хрещатик»-широка пішохідна вулиця довжиною 1,5 км з магазинами, ресторанами, кафе, фонтаном, біговими і велосипедними доріжками та величезною кількістю припаркованих автомобілів (рис. 2).

У цьому публічному просторі пропонуються варіанти проведення дозвілля для тих, хто веде спосіб життя представника середнього класу: відвідування кафе 3 винесеними на вулицю столиками, прогулянки 3 дітьми, вигулювання собак тощо. Вулиця в різний час доби наповнена людьми. Повсякденні практики дозвілля жителів даного ареалу новобудов $\epsilon$ характерними для міського способу життя. Водночас повсякденні практики проведення дозвілля жителів старої частини села відрізняються i, як правило, поєднуються із практиками здійснення покупок та отримання послуг. На вулицях, в центральному парку люди практично відсутні. Частково це можна пояснити не відповідністю зовнішнього вигляду i наповнення публічних просторів цієї частини села сучасним запитам, а частково поширенням сільського способу життя (рис. 3).

Незважаючи на зручне транспортне сполучення з Києвом («маршрутки» перевозять пасажирів до трьох станцій метро, до найближчої 3 яких можна доїхати за 15 хв.), більшість маршруток (за виключенням однієї прямої від ЖК «Софія») проходять через Софіївську Борщагівку з міст-супутників Вишневе, Боярка та села Петрівське, а отже в години пік виїхати 
iз села громадським транспортом проблематично. Вартість проїзду є вищою, ніж в межах міста Києва, оскільки Софіївська Борщагівка обслуговується приміським транспортом. У цій ситуації повсякденні практики переміщення жителями новобудов для поїздки на роботу чи навчання до Києва здійснюються переважно власним авто. Це збільшує навантаження на дороги села i поглиблює проблему пропускної здатності автошляхів та насиченості житлових комплексів власними автомобілями. А враховуючи ще й те, що в селі недостатня кількість дитячих садків, шкіл, закладів медичного обслуговування та інших об’єктів соціальної інфраструктури, ця проблема постає однією із найскладніших для вирішення.

Отже, гіпертрофування забудовниками житлової функції при недостатньому розвитку соціальної інфраструктури i, як наслідок, суттєвій залежності життєдіяльності мешканців Софіївської Борщагівки від головного міста-Києва - у соціально-економічному аспекті (місце роботи, місце навчання, місце отримання побутових, культурних, розважальних, рекреаційних, освітніх послуг тощо) (Провотар та ін. 2019) визначають конфігурацію простору повсякденного життя, який зосереджений в основному в Києві і частково у Софіївській Борщагівці.
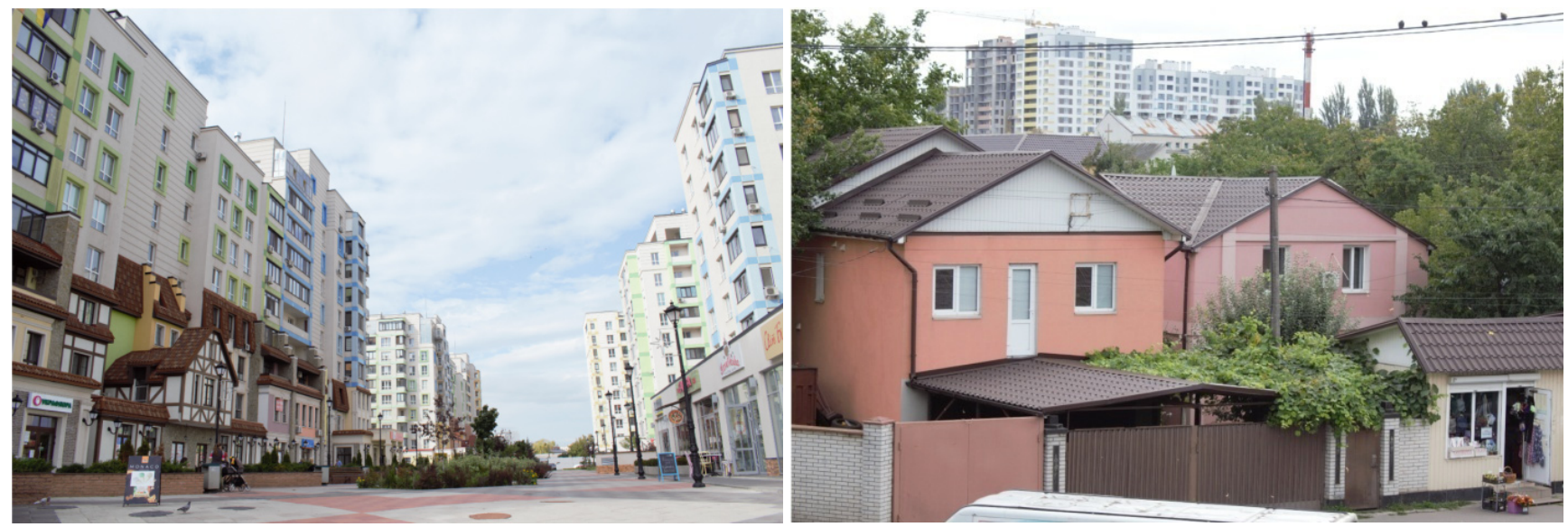

Рис. 4. Практики облаштування закладів сфери послуг м. Вишневе (Фото: О. Денисенко, 2019 рік)
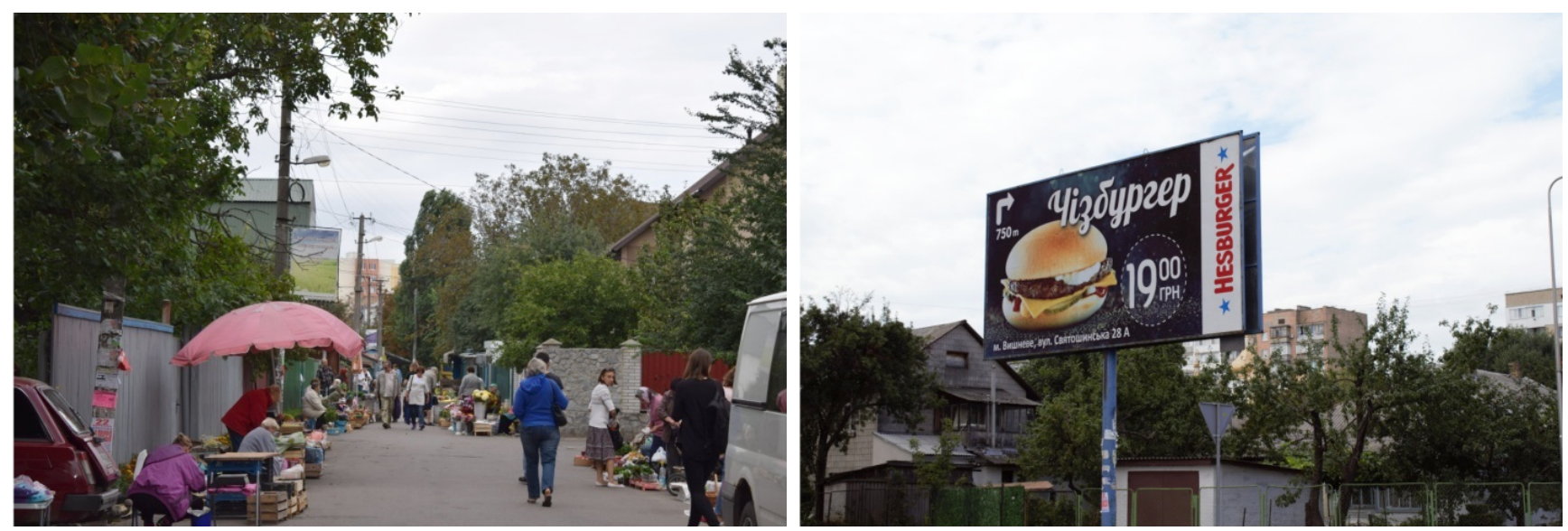

Рис. 5. Практики споживання у м. Вишневе (Фото: О. Денисенко, 2019 рік) 
Розглянемо кілька тенденцій, що вдало ілюструють домінуючі зміни повсякденних практик. Перша з них пов'язана 3 комерціалізацією низки побутових послуг та їх наближенням паралельно 3 віддаленням та ускладненням доступу до соціальних послуг, які надаються переважно державними та комунальними установами. Серед тих, які територіально наблизились до користувача, виділимо як типові традиційні послуги (продаж продуктів харчування, послуги обслуговування, поштові послуги тощо), так і нові для міста (певні види медичних послуг (мануальна терапія, масаж, стоматологія), спортивні (фітнес-клуби) тощо). 3 іншого боку, зміна традицій та правил забудови призвела до того, що значне збільшення житлового будівництва не супроводжувалось розбудовою міської мережі закладів соціальної інфраструктури (школи, дитячі садки, медичні заклади) та різким збільшенням частки містян, які задовольняють відповідні потреби за межами Вишневого. Наближення обслуговування населення у різних частинах міста реалізується по-різному. В одних районах відбувається комерціалізація перших поверхів житлових будинків, яку старій частині міста, так i у новобудовах. При цьому можна припустити, що зміна державних правил і норм будівництва призведе до появи тут більшої кількості приватних (у перспективі і державних) дитячих дошкільних та навчальних (молодші класи) закладів. В інших районах з'являються «алеї» сучасних малих архітектурних форм, прилеглі до публічних просторів нової житлової забудови, де надаються різноманітні послуги (рис. 4).

Такі фізичні зміни міського простору викликані та є відображенням зміни повсякденних практик, пов'язаних із проведенням дозвілля мешканцями міста, специфікою отримання ряду послуг нових або «оновлених» за формою та змістом. Перенесення практик спілкування 3 рідними, близькими, друзями за межі власного житла (наприклад, культура пиття кави, яка швидко поширилась у місті за останні п'ять років), спрощення можливостей комунікації із незнайомцями в межах публічних просторів, клубних закладів, кав'ярень та інших закладів змінює етику та естетику культури спілкування містян та посилює i «оновлює» міський спосіб життя, тобто урбанізує приміський простір.

У той же час, ускладнення отримання низки освітніх, медичних, соціальних послуг у безпосередній близькості до місця проживання підкреслює субурбанізований статус поселення. Це дещо посилює очікування вирішення гострих соціальних проблем містян шляхом приєднання м. Вишневого до столиці, що може розглядатись, як втрата рис та ідентичності субурбії на користь, власне, міських.

Друга тенденція у зміні повсякденних практик пов'язана з трансформацією традиційних закладів інфраструктури міста. Розкриємо ii на прикладі ринку в центрі південної частини Вишневого. Фізично він реконструйований, по периметру з'явились мережеві кав'ярні, продуктові магазини, бургерна тощо. Таким чином, тут перетинаються, взаємодіють та конкурують за вигідне місцерозташування традиційні «старі» (у т.ч. і характерні для сільської місцевості чи тісно взаємодіючі 3 нею) повсякденні практики. Так, на ринку і навколо нього можна «із землі» купити м'ясні, молочні продукти, рибу, овочі, зелень, фрукти, вирощені в підсобних господарствах жителів прилеглої до Вишневого сільської місцевості та садиб у межах міста. Водночас, усі найпрестижніші кав'ярні, заклади харчування, які з'явились за останні роки і презентують «оновлений» міський спосіб життя, теж концентруються тут (рис. 5). Подальша урбанізація цього приміського простору може призвести до появи на місці ринку торговельнорозважального центру. Це місце $є$ важливим 3 точки зору пізнання дотичності повсякденних комунікацій менш заможної частини міста (яка купує тут дешевшу продукцію) та більш заможної (яка відвідує ресторани та кав'ярні, проводить своє дозвілля), що має важливе значення для запобігання соціальній сегрегації в місті.

\section{Приміські простори Вінниці: зменшена копія Кисва чи особливий шлях?}

Серед великих міст України до 2014 року Вінниця вирізнялася одними 3 найвищих темпів демографічного зростання, у тому числі міграційного. Основною причиною цього є високий рівень якості життя у місті, що підтверджується численними національними рейтингами та оцінками. При цьому, незважаючи на триваюче активне житлове будівництво у межах Вінниці, відносні темпи демографічного зростання приміських просторів були вищими, ніж самого міста. Такий стан справ дозволяє віднести Вінницю до групи українських міст із одночасним перебігом процесів урбанізації та субурбанізації 3 переважанням останнього (Gnatiuk 2017).

Результати дослідження кейсу у с. Агрономічне вказують на складну взаємодію міських, приміських та сільських повсякденних практик у приміському просторі Вінниці. При цьому різні за походженням та соціальним статусом верстви населення села мають різне співвідношення таких практик. Нові жителі села, які мешкають у приватних садибах та котеджних містечках, належать до заможного прошарку населення і ведуть приміський спосіб життя, типовий для класичної субурбії. Майже всі види їх щоденних активностей (робота, освіта, споживання, дозвілля) відбувається у місті, куди вони дістаються власним автотранспортом. Самих місцевих мешканців на вулицях та на території садиб вдень майже не помітно - лише зрідка вулицею проїжджають автомобілі. Їх залучення до місцевих форм самоорганізації населення $є$ 
мінімальним. Фактично, село для них виконує функцію спального району, місцевою соціальною інфраструктурою вони майже не користуються, а транспортна інфраструктура їх цікавить лише у транзитному відношенні, оскільки забезпечує шлях між субурбією та містом. Винятками є кінний спортивний клуб «Вінниччина», окремі

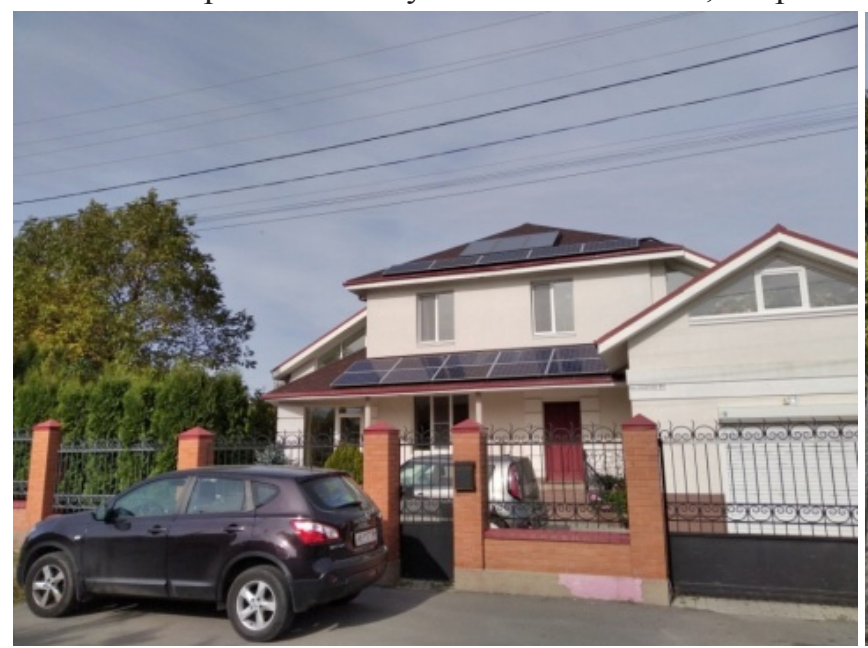

заклади ресторанного господарства та магазини, які пропонують послуги ландшафтного дизайну.

Житлові будинки та господарські споруди у приватних садибах нових мешканців також типові для «заможної» субурбії західного типу: збудовані 3 використанням сучасних матеріалів та мають індивідуальний стиль, часто 3 претензією на

Рис. 6. Житлова забудова нових мешканців с. Агрономічне (Фото: О. Гнатюк, 2019 рік)
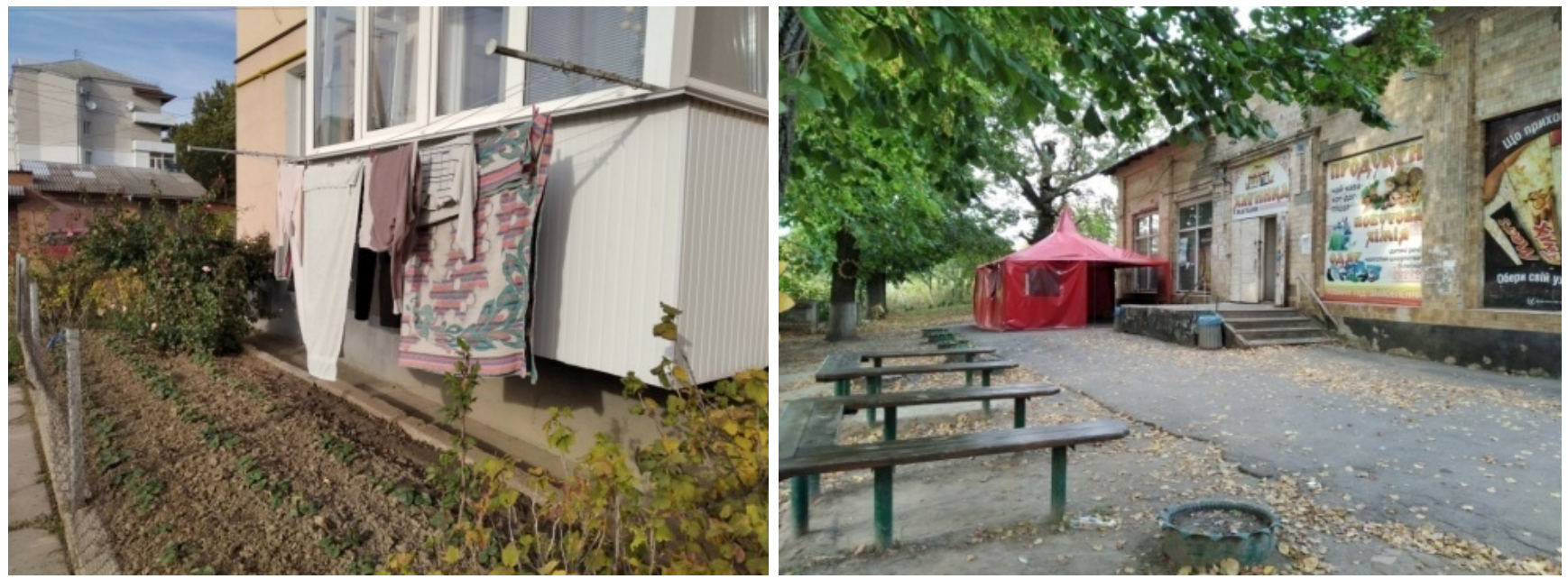

Рис. 7. Забудова історичного ядра с. Агрономічне (Фото: О. Гнатюк, 2019 рік)
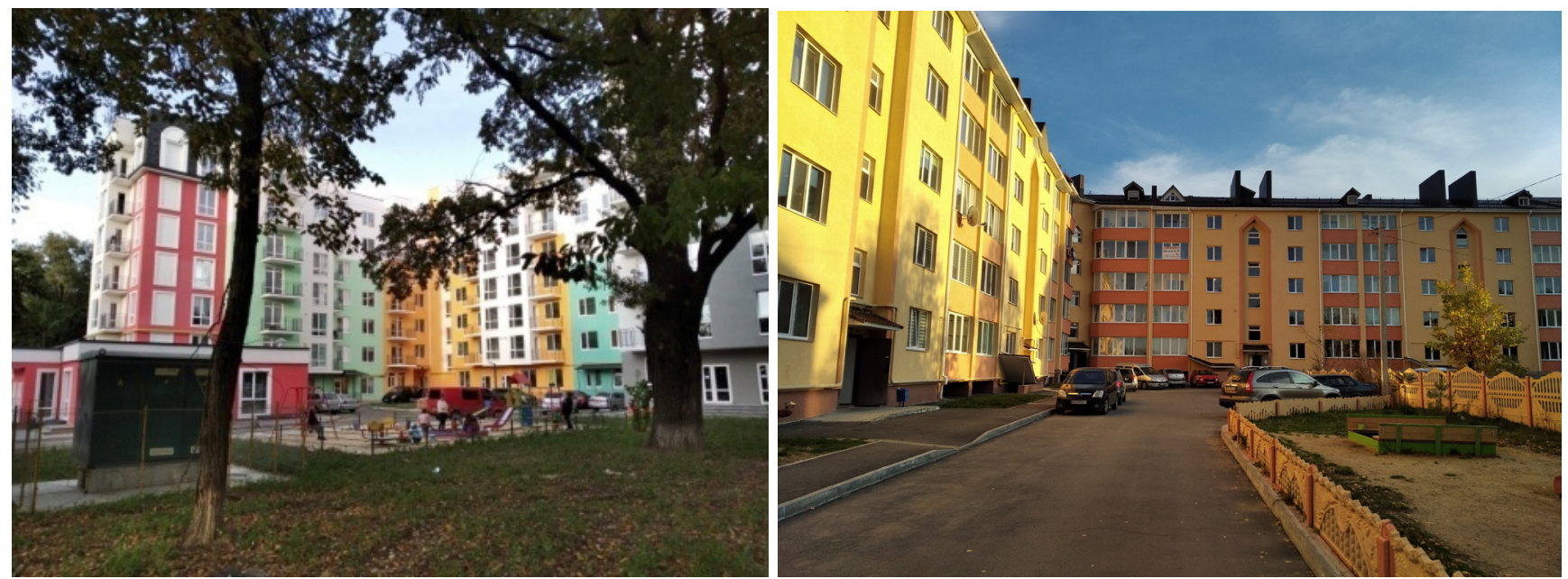

Рис. 8. Організація прибудинкової території новими жителями багатоквартирної забудови с. Агрономічне (Фото: О. Гнатюк, 2019 рік) 
вишуканість (у тому числі це стосується парканів, альтанок, колодязів тощо) (рис. 6). Паркани біля будинків, як правило, з кованого металу, каменю, рідше цегли або металопрофілю. Прибудинкова територія та вулична територія перед парканом має сучасний ландшафтний дизайн. Заїзди для автотранспорту часто виконані з використанням технології «зеленої парковки», тобто спеціальних сортів газонних трав та спеціальної залізобетонної основи для їх висаджування. Городи у цій частині села відсутні взагалі; сади, якщо й присутні, то представлені карликовими або колоновидними породами плодових дерев. Худобу та домашню птицю тут не тримають, хоча на території низки садиб розміщено невеликі пасіки. Проте у подвір'ях наявні породисті собаки. У деяких садибах помічено індивідуальні дитячі майданчики. На дахах багатьох будинків встановлено сонячні батареї. За територією багатьох садиб доглядають не власники, а спеціально найняті працівники.

Старожили, які проживають у селі 3 часів його функціонування як поселення при дослідній сільськогосподарській станції, демонструють поєднання приміських та сільських повсякденних практик. Ключовим проявом приміського способу життя є зростаюча залежність від міста як місця задоволення різноманітних потреб та одержання широкого спектру послуг, хоча ця залежність наразі не є настільки сильною, як у випадку нових жителів. Так чи інакше, зв'язки між передмістям та містом посилюються, поперше, через зростаючі вимоги мешканців до споживчих товарів та послуг, а по-друге, через інтенсифікацію транспортного сполучення Агрономічного 3 Вінницею (запровадження маршрутного таксі із високою періодичністю руху та подовження міської тролейбусної лінії до Аграрного університету, звідки до Агрономічного можна дійти пішки). Характерно, що одним із ключових побажань старожилів щодо подальшого розвитку села $є$ інтенсифікація руху маршрутних таксі, збільшення кількості маршрутів та подальше подовження тролейбусної лінії до самого Агрономічного.

Загалом ознаки сільського способу життя тут досі переважають. По-перше, характер благоустрою та використання прибудинкової території залишається типово сільським: територія навколо кожного будинку зайнята садами, городами та квітниками (деякі мешканці замінюють традиційні квітники класичними газонами); за окремими винятками, рівень благоустрою прибудинкових територій є низьким, вони неакуратні, часто занедбані та захаращені, зарослі чагарниками та деревами; типовим $\epsilon$ утримання худоби (свині, кози) та домашньої птиці у окремо розміщених або прибудованих хлівах та коморах. Усе вище перелічене стосується не лише приватних садиб, але й історичного ядра Агрономічного, де забудова за архітектурними особливостями має міські риси і представлена цегляними та панельними багатоквартирними будинками малої поверховості, що створює візуальний ефект сільського стилю життя у міському середовищі. Характерного колориту додає білизна, розвішена у подвір'ях для сушіння (рис. 7).

По-друге, традиційно сільськими залишаються способи дозвілля: спілкування із сусідами, відпочинок 3 дітьми та пікніки на території власного подвір'я, рибальство на ставку, візит до сільського кафетерію. По-третє, для старожилів типовим $є$ ведення підсобного господарства, як для задоволення власних потреб у продовольстві, так і з метою одержання прибутку від торгівлі. По-четверте, саме старожили складають кістяк сільської громади: вони продовжують працювати на території села, віддають своїх дітей на навчання до місцевої школи, беруть участь у облаштуванні громадського центру Агрономічного та збереженні місцевої ідентичності (наприклад, встановлення пам'ятного знака односельчанамжертвам військового конфлікту на сході України), формують соціальні групи за інтересами, які намагаються регулювати процеси використання місцевих ресурсів (наприклад, місцева спілка рибалок) тощо.

Спосіб життя нових жителів багатоквартирних будинків (житлових комплексів), які зводяться у Агрономічному, має проміжний характер відносно охарактеризованих вище груп. Хоча їх практики мобільності $є$ типово приміськими, оскільки вони щодня їздять до Вінниці приватним або громадським транспортом до місць прикладання праці, проте вони істотно інтегровані також до сільської громади (роблять покупки у селі, віддають дітей до місцевої школи, періодично користуються місцевими публічними просторами). При цьому характер організації прибудинкової території (газони, лавки, місця для паркування приватного автотранспорту) у місцях проживання таких мешканців $є$ типово міським (рис. 8). Заслуговує на увагу також той факт, що більшість велосипедистів у селі - це жителі нових багатоквартирних будинків.

Таким чином, повсякденні практики жителів Агрономічного відзначаються строкатістю, гібридністю і перебувають у стані трансформації. Рушійною силою трансформації $€$ швидка кардинальна зміна вікової та соціальноекономічної структури населення внаслідок інтенсивної міграції. Домінуючими процесами $€$ поява приміських практик (субурбанізація сільського поселення) із наступною асиметричною взаємодією/конкуренцією приміських та сільських практик: інтенсивним проникненням приміських практик у життя старожилів (наприклад, практики мобільності) та доволі обмеженим проникненням сільських практик у життя нових мешканців (наприклад, суничні городи біля елітних котеджів). Подальша трансформація, яка полягала би у поступовому заміщенні сільських та приміських практик міськими, на сьогодні гальмується обмеженими кількістю та спектром місць прикладання праці, а також майже 
цілковитою відсутністю спеціально обладнаних місць відпочинку та дозвілля загального користування, у тому числі відкритих публічних просторів. Такий рівень благоустрою та сервісу задовольняє потреби більшості старожилів, але не відповідає запитам новоприбулих мешканців.

\section{Висновки}

Соціальні та економічні трансформації приміських просторів суттєво змінюють спосіб життя мешканців та їх повсякденні практики вони повсякчас оновлюються та видозмінюються, відтворюючись у нових формах. А принципові зміни приміських просторів, що проявляються, зокрема, у вибуховому зростанні кількості мешканців, викликають радикальні зміни повсякденних практик. Пізнання взаємозв'язку мешканців 3 містом i передмістям через повсякденні практики мешканців - це пізнання «живого», а не лише статичного міста.

Перетворення практик $є$ відображенням трансформації міського середовища, що зазнало суттєвих змін, зокрема, у зв'язку з появою нових мешканців, які орієнтовані на центральне місто. Відповідно до типізації взаємодій між міськими та сільськими просторами, запропонованої Е. Кастлом, Дж. Ву та Б. Вебером (Castle et al. 2011), в основі якої лежить орієнтація людини на той чи інший тип простору, у субурбії зросла частка мешканців, орієнтованих на зовнішні взаємодії та задоволення потреб у центральному місті. Водночас частина мешканців традиційно орієнтовані на задоволення потреб у субурбії. Сукупність цих процесів призводить до «зіткнення» та «накладання» старих і нових повсякденних практик, їх взаємного перетворення та деякої гібридизації.

Аналіз кейсів показує, що рушійні сили трансформації приміських просторів Києва та Вінниці в загальних рисах є подібними. Подібними $\epsilon$ також наслідки трансформаційних процесів: радикальна зміна структури населення; втрата або гібридний характер місцевої ідентичності приміських поселень; випереджаючий розвиток житлової забудови за відставання розвитку відповідної інженерної та соціальної інфраструктури; наростаюча неоднорідність, фрагментарність та поліцентричність приміських просторів; посилення залежності субурбії від центрального міста.

Зміни повсякденних практик у приміських зонах обох міст також демонструють певну подібність. Тому за більшістю процесів трансформації приміської зони кейс Агрономічного нагадує кейс Софіївської Борщагівки у мініатюрі. Проте, існують також відмінності не лише кількісного, але i якісного характеру, які можна пояснити ефектом відмінності масштабу (демографічного, економічного, культурного потенціалу двох міст), але опосередковано, шляхом переходу кількісних змін у якісні. На відміну від Києва, приміські простори якого виступають потужним атрактором мігрантів з усієї країни, Вінниця не $є$ настільки притягальним полюсом для мігрантів 3 інших територій. Ця обставина, разом із наявністю у Вінниці потужного (за українськими мірками) середнього класу, призвела до переважання «екологічної» мотивації переїзду до передмістя, наслідком чого стало домінування відцентрових міграційних потоків у приміських просторах Вінниці та домінування субурбанізації західного типу. Жителі такої субурбії, на відміну від випадку «багатоповерхової субурбанізації» (Мезенцев і Мезенцева 2017), схильні зберігати стійкий приміський спосіб життя, що додатково посилює залежність вінницької субурбії від центрального міста. У свою чергу, ця обставина призводить до гальмування розвитку соціальнопобутової інфраструктури у передмісті, створюючи ефект замкненого кола. 3 іншої сторони, менші абсолютні масштаби житлової субурбанізації навколо Вінниці мають наслідком менший тиск на вже наявну соціальну та інженерну інфраструктуру субурбії, що стимулює до ㄲï використання місцевими мешканцями. Крім того, при порівняльній оцінці розвитку приміських просторів двох міст варто мати на увазі, що субурбанізація навколо Вінниці розпочалась пізніше, ніж навколо Києва, тому наявні якісні відмінності можуть пояснюватися також відмінностями у стадіях розвитку (Borén and Gentile 2007).

\section{References:}

1. Anderson K. Introduction: After Sprawl: Post-Suburban Sydney. In: After Sprawl: Post-Suburban Sydney (eds.: K. Anderson, R. Dobson, F. Allon, and B. Neilson). E-Proceedings of 'Post-Suburban Sydney: The City in Transformation' Conference, Sydney, 2006.

2. Borén T., Gentile M. Metropolitan Processes in Post-Communist States: an Introduction. Geografiska Annaler, Series B: Human Geography, 2017, vol. 89(2), pp. 95-110.

3. Castle E., Wu J., Weber, B. Place orientation and rural-urban interdependence. Applied Economic Perspectives and Policy, 2011, vol. 33, pp. 179-204.

4. Chaney D. Cultural Change and Everyday Life. Basingstoke: Palgrave, 2002.

5. Charmes E., Keil R. The Politics of Post-Suburban Densification in Canada and France. International Journal of Urban and Regional Research, 2015, vol. 39(3), pp. 581-602.

6. Crawford M. Afterword. In: Making Suburbia: New Histories of Everyday America (eds.: J. Archer, P. J. P. Sandul, and K. Solomonson). Minneapolis: University of Minnesota Press, 2015, pp. 381-387. 
7. Drummond L., Labbé D. We're a Long Way from Levittown, Dorothy: Everyday Suburbanism as a Global Way of Life. In: Suburban Constellations: Governance, Land and Infrastructure in the 21st Century. (ed.: R. Keil). Berlin: Jovis Verlag, 2013, pp. 46-51.

8. Dymitrow M., Stenseke M. Rural-Urban Blurring and the Subjectivity Within. Rural Landscapes: Society, Environment, History, 2016, vol. 3(1), pp. 1-13.

9. Fava S. F. Suburbanism as a way of life. American Sociological Review, 1956, vol. 21(1), pp. 34-37.

10. Gnatiuk O. Demographic dimension of suburbanization in Ukraine in the light of urban development theories. Acta Universitatis Carolinae Geographica, 2017, vol. 52(2), pp. 13-25.

11. Harris R. Meaningful types in a world of suburbs. Research in Urban Sociology, 2010, vol. 10, pp. 15-47.

12. Harris R. Suburbanization and Suburbanism. In: International Encyclopedia of the Social \& Behavioral Sciences (ed.: J. D. Wright). Second Edition. Oxford: Elsevier, 2015, pp. 660-666.

13. Hillier B., Hanson J. The social logic of space. Cambridge: Cambridge University Press, 1984.

14. Hirt S. Iron Curtains: Gates, Suburbs and Privatization of Space in the Post-Socialist City. Oxford: WileyBlackwell, 2012.

15. Horton J., Kraftl P. Cultural Geographies. An Introduction. New York: Routledge, 2014.

16. Jessen J., Roost F. Editorial: Refitting Suburbia - Umbau der Siedlungsstrukturen des 20. Jahrhunderts. In: Refitting Suburbia: Erneuerung der Stadt des 20. Jahrhunderts in Deutschland und den USA. Berlin: Jovis, 2015, pp. 7-22.

17. Keil R. Suburban Planet: Making the World Urban from the Outside in. Cambridge: Polity Press, 2018.

18. Knox P., Pinch S. Urban Social Geography. Harlow: Pearson Education, 2010.

19. Kotkin J. The New Suburbanism. A Realist's Guide to the American Future. A Report produced by The Planning Center, 2005.

20. MacKay H. Introduction. In: Consumption and Everyday Life (ed.: H. MacKay). London: Sage, 1997, pp. 1-12.

21. Massotti L. H. (1973) Prologue: suburbia reconsidered - myth and counter-myth. In: The Urbanization of the Suburbs (eds.: L. H. Masotti, J. K. Hadden). London: Sage, 1973, pp. 15-22.

22. McManus R., Ethington P. Suburbs in transition. New approaches to suburban history. Urban History, 2007, vol. 34(2), pp. 317-337.

23. Mezentsev, K. Vstup: primìs'kì prostori, ŝo zmìnûût'sâ ta vinikaût' [Introduction: Changing and Emerging Suburban Spaces]. In: Urban Ukraine: in the Epicenter of Spatial Changes (eds.: K. Mezentsev, Ya. Oliynik, and N. Mezentseva). Kyiv: Phoenix, 2017, pp. 261-267. (In Ukrainian).

24. Mezentsev K. V. Regìonal'nij rozvitok: činniki nerìvnomìrnostì ta formuvannâ periferiï [Regional Development: factors of unevenness and formation of the periphery]. Scientific Bulletin of Lesya Ukrainka Volyn National University. Series 6. Geographical Sciences, 2012, vol. 9(234), pp. 20-26. (In Ukrainian).

25. Mezentsev K., And Mezentseva, N. Žitlova suburbanìzaciâ v Ukraïnì: trendi ta vìdmìnnostì [Residential suburbanization in Ukraine: trends and differences]. In: Urban Ukraine: in the Epicenter of Spatial Changes (eds.: K. Mezentsev, Ya. Oliynik, and N. Mezentseva). Kyiv: Phoenix, 2017, pp. 268-287. (In Ukrainian).

26. Mezentsev K., Mezentseva N. Socìal'na geografiâ: sučasnì fokusi ta pìdhodi [Social Geography: contemporary focuses and approaches]. In: Geografična nauka ta osvita: vìd konstataciï do konstruktivizmu [Geographical Science and Education: from statement to constructivism]. Kyiv, 2018, pp. 25-28. (In Ukrainian).

27. Mikelbank B. A. A typology of U.S. suburban places. Housing Policy Debate, 2004, vol. 15(4), pp. 935-964.

28. Ortega A. A. C. Desakota and Beyond: Neoliberal Production of Suburban Space in Manila's Fringe. Urban Geography, 2012, vol. 33(8), pp. 1118-1143.

29. Ouředníček M. Differential Suburban Development in Prague Urban Region. Geografiska Annaler, Series B: Human Geography, 2007, vol. 89(2), pp. 111-126.

30. Phelps N. A. Introduction: Old Europe: New Suburbanization? In: Old Europe: New Suburbanization. Governance, Land and Infrastructure in European Suburbanization (ed: N. A. Phelps). Toronto: University of Toronto Press, 2017, pp. 3-17.

31. Phelps N. A., Tarazona Vento A., Roitman S. The suburban question: grassroots politics and place making in Spanish suburbs. Environment and Planning C: Government and Policy, 2015, vol. 33(3), pp. 512-532.

32. Provotar N., Melnychuk A., Gnatiuk O., Denysenko O. (2019) Changing everyday practices in suburban spaces: a methodology to investigate local trends. Ekonomichna ta Sotsialna Geografiya, vol. 81, pp. 34-41. (In Ukrainian)

33. Schneider W. The suburban century begins. Atlantic Monthly, July 1992, pp. 33-44.

34. Shen J., Wu F. Moving to the suburbs: demand-side driving forces of suburban growth in China. Environment and Planning A, 2013, vol. 45(8), pp. 1823-1844.

35. Shove E., Pantzar M., Watson M. The dynamics of social practice. Everyday Life and how it changes. SAGE Publications, 2012.

36. Smith, S.J., Pain, R., Marston, S.A., and Jones III, J.P. Introduction: Situating Social Geography. In: The SAGE Handbook of Social Geographies (eds.: S. J. Smith, R. Pain, S. A. Marston, and J. P. Jones III). London: SAGE Publications, 2010, pp. 1-39.

37. Soja E. W. Regional urbanization and the end of the metropolitan era. In: The new Blackwell companion to the city. (eds.: G. Bridge, S. Watson). London: Wiley-Blackwell, 2011, pp. 679-689. 
38. Stanilov K., Sýkora L. (eds.) Confronting Suburbanization: Urban Decentralization in Postsocialist Central and Eastern Europe. Oxford: Wiley-Blackwell, 2014.

39. Walks A. Suburbanism as a Way of Life, Slight Return. Urban Studies, vol. 50(8), pp. 1471-1488.

\section{Список використаних джерел:}

1. Anderson K. Introduction: After Sprawl: Post-Suburban Sydney / K. Anderson / E-Proceedings of 'PostSuburban Sydney: The City in Transformation' Conference / K. Anderson, R. Dobson, F. Allon, B. Neilson B. (eds.). - Sydney, 2006.

2. Borén T. Metropolitan Processes in Post-Communist States: an Introduction/ T. Boren and M. Gentile // Geografiska Annaler, Series B: Human Geography. - 2007. - Vol. 89 (2). - P. 95-110.

3. Castle E. Place orientation and rural-urban interdependence / E. Castle, J. Wu, B. Weber // Applied Economic Perspectives and Policy. - 2011. - Vol. 33. - P. 179-204.

4. Chaney D. Cultural Change and Everyday Life. Basingstoke: Palgrave, 2002.

5. Charmes E. The Politics of Post-Suburban Densification in Canada and France / E. Charmes, R. Keil // International Journal of Urban and Regional Research. - 2015. - Vol. 39(3). - P. 581-602.

6. Crawford M. Afterword / M. Craiford / Making Suburbia: New Histories of Everyday America / J. Archer, P. J. P. Sandul, K. Solomonson (eds.). - Minneapolis: University of Minnesota Press, 2015. - P. 381-387.

7. Drummond L. (2013) We're a Long Way from Levittown, Dorothy: Everyday Suburbanism as a Global Way of Life / L. Drummond, D. Labbé / Suburban Constellations: Governance, Land and Infrastructure in the 21st Century / R. Keil (ed.). - Berlin: Jovis Verlag, 2013. - P. 46-51.

8. Dymitrow M. Rural-Urban Blurring and the Subjectivity Within / M. Dymitrow, M. Stenseke // Rural Landscapes: Society, Environment, History. - 2016. - Vol. 3(1). - P. 1-13

9. Fava S. F. Suburbanism as a way of life / S. F. Fava // American Sociological Review. 1956. - Vol. 21(1). - P. 34-37.

10. Gnatiuk O. Demographic dimension of suburbanization in Ukraine in the light of urban development theories / O. Gnatiuk // Acta Universitatis Carolinae Geographica. - 2017. - Vol. 52(2). - P. 13-25.

11. Harris R. Meaningful types in a world of suburbs / R. Harris // Research in Urban Sociology. - 2010. - Vol. 10. - P. 15-47.

12. Harris R. Suburbanization and Suburbanism / R. Harris / J. D. Wright (ed.) / International Encyclopedia of the Social \& Behavioral Sciences. Second Edition. - Oxford: Elsevier, 2015. - P. 660-666.

13. Hillier B. The social logic of space / B. Hillier, J. Hanson. - Cambridge: Cambridge University Press, 1984.

14. Hirt S. Iron Curtains: Gates, Suburbs and Privatization of Space in the Post-Socialist City / S. Hirt. - Oxford: Wiley-Blackwell, 2012.

15. Horton J. Cultural Geographies. An Introduction / J. Horton, P. Kraftl. - New York: Routledge, 2014.

16. Jessen J. Editorial: Refitting Suburbia - Umbau der Siedlungsstrukturen des 20. Jahrhunderts / J. Jessen, F. Roost / Refitting Suburbia: Erneuerung der Stadt des 20. Jahrhunderts in Deutschland und den USA. - Berlin: Jovis, 2015. - P. 7-22.

17. Keil R. Suburban Planet: Making the World Urban from the Outside in / R. Keil. -Cambridge: Polity Press, 2018.

18. Knox P. Urban Social Geography / P. Knox, S. Pinch. - Harlow: Pearson Education, 2010.

19. Kotkin J. The New Suburbanism. A Realist's Guide to the American Future / J. Kotkin / A Report produced by The Planning Center, 2005.

20. MacKay H. Introduction / H. MacKay / Consumption and Everyday Life / MacKay H. (ed.). - London: Sage, 1997. - P. 1-12.

21. Massotti L. H. Prologue: suburbia reconsidered - myth and counter-myth / L. H. Masotti / The Urbanization of the Suburbs / L. H. Masotti and J. K. Hadden (eds.). - London: Sage, 1973. - P. 15-22.

22. McManus R. Suburbs in transition. New approaches to suburban history / R. McManus, P. Ethington // Urban History. - 2007. - Vol. 34(2). - P. 317-337.

23. Мезенцев К. Вступ: приміські простори, що змінюються та виникають / К. Мезенцев / Урбаністична Україна: в епіцентрі просторових змін: монографія / за ред. К. Мезенцева, Я. Олійника, Н. Мезенцевої. - К.: Фенікс, 2017. - С. 261-267.

24. Мезенцев К. В. Регіональний розвиток: чинники нерівномірності та формування периферії / К. В. Мезенцев // Науковий вісник Волинського національного університету імені Лесі Українки. Географічні науки. - 2012. - № 9. - С. 20-26.

25. Мезенцев К. Житлова субурбанізація в Україні: тренди та відмінності / К. Мезенцев, Н. Мезенцева / Урбаністична Україна: в епіцентрі просторових змін : монографія / за ред. К. Мезенцева, Я. Олійника, Н. Мезенцевої. - К.: Фенікс, 2017. - С. 268-287.

26. Мезенцев К. Соціальна географія: сучасні фокуси та підходи / К. Мезенцев, Н. Мезенцева / Географічна наука та освіта: від констатації до конструктивізму. - Київ, 2018. - С. 25-28.

27. Mikelbank B. A. A typology of U.S. suburban places / B. A. Mikelbank // Housing Policy Debate. - 2004. - Vol. 15(4). - P. 935-964. 
28. Ortega A. A. C. Desakota and Beyond: Neoliberal Production of Suburban Space in Manila's Fringe / A. A. C. Ortega // Urban Geography. - 2012. - Vol. 33(8). - P. 1118-1143.

29. Ouředníček M. Differential Suburban Development in Prague Urban Region / M. Ouředníček // Geografiska Annaler, Series B: Human Geography. - 2007. - Vol. 89(2). - P. 111-126.

30. Phelps N. A. Introduction: Old Europe: New Suburbanization? / N. A. Phelps / Old Europe: New Suburbanization. Governance, Land and Infrastructure in European Suburbanization / Phelps, N.A. (ed.). - Toronto: University of Toronto Press, 2017. - P. 3-17.

31. Phelps N. A. The suburban question: grassroots politics and place making in Spanish suburbs / N. A. Phelps, A. Tarazona Vento, S. Roitman // Environment and Planning C: Government and Policy. - 2015. - Vol. 33(3). - P. 512-532.

32. Провотар Н. Мінливі повсякденні практики у приміських просторах: методика дослідження місцевих трендів / Н. Провотар, А. Мельничук, О. Гнатюк, О. Денисенко // Економічна та соціальна географія. - 2019. - Вип. 81. - С. 34-41.

33. Schneider W. The suburban century begins / W. Schneider. Atlantic Monthly. - 1992. - July. - P. 33-44.

34. Shen J. Moving to the suburbs: demand-side driving forces of suburban growth in China / J. Shen and F. Wu // Environment and Planning A. - 2013. - Vol. 45(8). - P. 1823-1844.

35. Shove E. The dynamics of social practice. Everyday Life and how it changes / E. Shove, M. Pantzar, M. Watson. - SAGE Publications, 2012.

36. Smith S. J. Introduction: Situating Social Geography / S. J. Smith, R. Pain, S. A. Marston, J. P. Jones III / The SAGE Handbook of Social Geographies / S. J. Smith, R. Pain, S. A. Marston, J. P. Jones III (eds). - London: SAGE Publications, 2010. - P. 1-39.

37. Soja E. W. Regional urbanization and the end of the metropolitan era / E. W. Soja / The new Blackwell companion to the city / G. Bridge, S. Watson (eds.). - London, Wiley-Blackwell, 2011. -P. 679-689.

38. Stanilov K. Confronting Suburbanization: Urban Decentralization in Postsocialist Central and Eastern Europe / K. Stanilov, L. Sýkora (eds.). - Oxford: Wiley-Blackwell, 2014.

39. Walks A. (2013) Suburbanism as a Way of Life, Slight Return / A. Walks // Urban Studies. - 2013. - Vol. 50(8). - P. 1471-1488. 